\title{
Solid-Phase Extraction of Trace Amounts of Uranium(VI) in Environmental Water Samples Using an Extractant-Impregnated Resin Followed by Detection with UV-Vis Spectrophotometry
}

\author{
Ahmad Hosseini-Bandegharaei, Masoud Sarwghadi, Aliasghar Heydarbeigi, \\ Seyyed Hossein Hosseini, and Mehdi Nedaie \\ Water Division, Department of Engineering, Kashmar Branch, Islamic Azad University, 96716-97718 Kashmar, Iran \\ Correspondence should be addressed to Ahmad Hosseini-Bandegharaei; ahoseinib@yahoo.com
}

Received 19 May 2013; Revised 14 September 2013; Accepted 19 September 2013

Academic Editor: Daryoush Afzali

Copyright (C) 2013 Ahmad Hosseini-Bandegharaei et al. This is an open access article distributed under the Creative Commons Attribution License, which permits unrestricted use, distribution, and reproduction in any medium, provided the original work is properly cited.

\begin{abstract}
A stable extractant-impregnated resin (EIR) containing Chrome Azurol B was prepared using Amberlite XAD-2010 as a porous polymeric support. The new EIR was employed for trace separation and preconcentration of U(VI) ion followed by spectrophotometric determination with the arsenazo III procedure. CAB/XAD-2010 exhibited excellent selectivity for U(VI) ion over coexisting ions. Experimental parameters including $\mathrm{pH}$, contact time, shaking speed, and ionic strength were investigated by batch extraction methods. Maximum sorption of U(VI) ions occurred at pH 4.3-6.9. The capacity of EIR was found to be $0.632 \mathrm{mmol} \cdot \mathrm{g}^{-1}$. Equilibrium was reached in $25 \mathrm{~min}$ and the loading half-time, $t_{1 / 2}$, was less than $6 \mathrm{~min}$. The equilibrium adsorption isotherm of U(VI) was fitted with the Langmuir adsorption model. In addition, a column packed with CAB/XAD-2010 was used for column-mode separation and preconcentration of $\mathrm{U}(\mathrm{VI})$ ion. For the optimization of the dynamic procedure, effects of sample volume, sample and eluent flow rate, eluent concentration, and its volume were investigated. The preconcentration factors for U(VI) were found out to be 160 . But, for convenience, a preconcentration factor of 150 was utilized for the column-mode preconcentration. The dynamic procedure gave a detection limit of $5.0 \times 10^{-10} \mathrm{~mol} \cdot \mathrm{L}^{-1}\left(0.12 \mu \mathrm{g} \cdot \mathrm{L}^{-1}\right)$ for $\mathrm{U}(\mathrm{VI})$ ion. The proposed dynamic method showed good performance in analyzing environmental water samples.
\end{abstract}

\section{Introduction}

Nowadays, a great attention is paid to the analytical monitoring of uranium in environmental samples due to its serious toxic effects even at low concentrations $[1,2]$. Among the eminent techniques developed for the determination of uranium in environmental samples [3-7], preconcentrative separation of trace amounts of uranium from these samples followed by spectrophotometric determination, using arsenazo III procedure, has attracted much attention in the last decades [8-13]. This fact is due to availability, easy operation, and relative low operational and instrumental costs.

Solid-phase extraction (SPE) has come to the forefront compared with other preconcentration techniques because of the development of solid adsorbents, including chelating polymeric supports, and the advantages in the use of these adsorbents in metal ions preconcentration. SPE offers several important advantages such as [12-18] the following:

(i) higher enrichment factors,

(ii) absence of emulsion,

(iii) safety with respect to hazardous samples,

(iv) minimal costs due to low consumption of reagents,

(v) flexibility,

(vi) ease of automation.

In addition, several properties such as selectivity, simplicity of equipment, ease of operation, and the possibility of using adsorbents for many separation and preconcentration cycles without losses in the metal ion sorption capacity have made their use popular. 
Extractant-impregnated resins, EIRs, have recently been developed for designing chelating polymeric supports and separating transition metal ions from aqueous media, because the preparation of chelating polymeric ion exchangers with chelating ligand connected to the polymer matrix by chemical bonds is usually very complex, time consuming, and costly. The preparation of chelating polymeric ion exchangers by the impregnation methods is exceedingly easy to perform, merely requiring stirring of an adequate extractant and the polymeric support. In addition, there is a wide choice of reagents for desired selectivity [19-26]. Therefore, by preparing a stable impregnated resin, one can combine the specific properties of an extractant, such as its selectivity, with the advantages of solid-ion-exchange technology for processing highly diluted solutions. Consequently, the extractantimpregnated resins (EIRs) are more suitable than conventional solvent extraction for recovering a specified metal ion with high selectivity. Among the studies concerning EIRs, several studies have been reported for polymeric supports in which an inert support is impregnated with a selective organic extractant to produce a solid sorbent used to separate and preconcentrate $\mathrm{U}(\mathrm{VI})$ from various analytical matrices [12, 13, 23-26].

In the followup of our group researches on the EIRs applications $[12,13,27-31]$, this work focuses on the selective separation and preconcentration of trace amounts of uranium in various environmental water samples using a new EIR containing Amberlite XAD-2010 resin beads impregnated with Chrome Azurol B. Our new EIR sorbent showed excellent selectivity for U(VI) sorption from aqueous solutions. The adsorbed U(VI) ions stripped easily with $0.50 \mathrm{M} \mathrm{HCl}$ solution and the regenerated EIR could be used in subsequent cycles for $\mathrm{U}(\mathrm{VI})$ separation and preconcentration. In this paper, performance testing of the new EIR for solid-phase extraction of uranium is discussed.

\section{Experimental}

2.1. Reagents and Apparatus. Deionized water was used to prepare all solutions. Unless stated, all solvents and reagents used were analytical reagent grade and purchased from Merck (Darmstadt, Germany). Stock standard solution of $\mathrm{U}(\mathrm{VI})$ was prepared by dissolving the appropriate amounts of uranyl nitrate in deionized water, acidified with a small amount of $\mathrm{HNO}_{3}$. The solutions of uranium(VI) were standardized gravimetrically

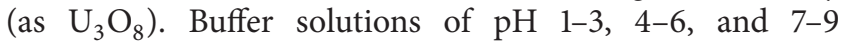
were prepared by mixing appropriate ratios of $0.1 \mathrm{M}$ $\mathrm{HCl}$ and $\mathrm{KCl}, 0.5 \mathrm{M}$ acetic acid and ammonium acetate, and $0.5 \mathrm{M}$ ammonia and $\mathrm{NH}_{4} \mathrm{Cl}$ solutions, respectively. Chrome Azurol B (Chromazurol B; Mordant Blue 1; CI Mordant Blue 1; CI Mordant Blue 1, free acid; Eriochrome Blue SBB; Eriochrome Azurol B free form; Eriochrome Azurol 6B free form; EINECS 239-098-7), CAB (4-[(3Carboxy-5-methyl-4-oxo-1-cyclohexa-2,5-dienylidene)(2,6dichlorophenyl)methyl]-2-hydroxy-3-ethylbenzoic acid), and Amberlite XAD-2010 (surface area of $660 \mathrm{~m}^{2} \mathrm{~g}^{-1}$, pore diameter $28.0 \mathrm{~nm}$, and bead size 20-60 mesh) were obtained from Sigma Chem. Co., St. Louis. The surface area, pore diameter, and mesh size of the resin were quoted by the supplier.

For the determination of $\mathrm{U}(\mathrm{VI})$ in solutions using arsenazo III procedure, adsorption measurements were recorded on a Shimadzu double-beams UV-Vis (2150-PC, Japan) spectrophotometer equipped with quartz cuvettes of $1 \mathrm{~cm}$ thickness. The $\mathrm{pH}$ measurements were made on a model PHS3BW pH-meter (Bel, Italy). A Fine PCR automatic shaker model SH30L-t, Korea, was used for the batch experiments. The flow of sample and eluent solutions through the short column was controlled with a BT100-1L peristaltic pump and a DG-2 head pump (Longer pump, China). A Sartorius membrane filter of pore size $0.45 \mu \mathrm{m}$ was used to remove particles in analysis of real samples.

2.2. Preparation of the EIR. The dry procedure was used for preparing CAB-impregnated XAD-2010 resin beads [29]. Before the impregnation process, Amberlite XAD-2010 resin beads were treated with 1:1 methanol-water solution containing $6 \mathrm{M} \mathrm{HCl}$ for $12 \mathrm{~h}$ in order to remove remaining monomers and other types of impurities which may be found with the fabricated beads. The resin was thoroughly rinsed with doubly-distilled water and placed into a drying oven at $323 \mathrm{~K}$ for $30 \mathrm{~min}$. To prepare the impregnated resin, portions of Amberlite XAD-2010 resin ( $1 \mathrm{~g}$ of dry resin) were transferred into a series of glass stoppered bottles containing different concentrations of CAB in $200 \mathrm{~mL}$ methanol, which was used as the solvent. The mixtures were slowly shaken for $10 \mathrm{~h}$ to complete the impregnation process and then heated at $333 \mathrm{~K}$ in a drying oven to remove the solvent. Each EIR sample was then transferred to a porous filter and washed successively with $\mathrm{HCl}(3 \mathrm{M})$ solution and large amounts of distilled water until no CAB was found in the filtrate, spectrophotometrically. Finally, the impregnated resins were dried at $323 \mathrm{~K}$ and weighed. The amount of CAB impregnated on/in the resin beads was determined from the weight change of polymeric resin. To avoid surface peeling and cracking, which cause the leaching of some extractant molecules from the resin beads, the prepared EIR beads were stored under deionized water in a stoppered glass bottle.

\subsection{Sorption Procedures}

2.3.1. Static Sorption of U(VI) Ions. A batch technique was used to sorb the U(VI) ions at $298 \pm 1 \mathrm{~K}$. The $100 \mathrm{~mL}$ aliquots of aqueous solution containing suitable concentrations of $\mathrm{U}(\mathrm{VI})$ were taken in glass-stoppered bottles and adjusted to a known $\mathrm{pH}$. The CAB-impregnated XAD-2010 resin beads $(0.150 \mathrm{~g})$ were added to each bottle and the mixtures were equilibrated for a fixed period of time. The EIR beads were filtered and the sorbed U(VI) ions were desorbed by shaking with $5 \mathrm{~mL}$ of $0.50 \mathrm{M} \mathrm{HCl}$. The desorbed U(VI) ions were measured spectrophotometrically by the arsenazo III procedure described in Section 2.4. For adsorption equilibrium studies, the mixtures were shaken at a fixed temperature using a temperature controlled shaker set at $180 \mathrm{rpm}$ for a period of desired time at the optimum $\mathrm{pH}$ value and desired 
ionic strength. After that, the suspensions were filtered and the filtrates were analyzed spectrophotometrically by the arsenazo III procedure described in Section 2.4. The amounts of uranium adsorbed per gram of the EIR beads were calculated at various time " $t$ " $\left(q_{t}\right)$ and at equilibrium $\left(q_{e}\right)$ by the mass balance equations:

$$
q_{t}=\frac{\left(C_{0}-C_{t}\right) V}{m}, \quad q_{e}=\frac{\left(C_{0}-C_{e}\right) V}{m},
$$

where $q_{t}$ is the amount of the uranium adsorbed onto the EIR beads at time " $t$ " $\left(\mathrm{mg} \cdot \mathrm{g}^{-1}\right), q_{e}$, the amount of the uranium adsorbed onto the EIR beads at equilibrium $\left(\mathrm{mg}^{-1}\right), C_{0}$, the initial concentration of $\mathrm{U}(\mathrm{VI})$ in the aqueous solutions (mg. $\left.\mathrm{L}^{-1}\right), C_{t}$, the $\mathrm{U}(\mathrm{VI})$ concentration remaining in the solutions at time " $t$ " $\left(\mathrm{mg} \cdot \mathrm{L}^{-1}\right), C_{e}$, the equilibrium concentration of $\mathrm{U}(\mathrm{VI})$ in the solutions $\left(\mathrm{mg} \cdot \mathrm{L}^{-1}\right), V$, the volume of the solutions used $(L)$, and $m$, the weight of the EIR beads used in $\mathrm{g}$.

2.3.2. Dynamic Sorption of $U(V I)$ Ions. Five hundred milligrams of new EIR was slurried in water and then packed into a polyethylene column with an internal diameter of $0.4 \mathrm{~cm}$. The ends were fitted with a small amount of glass wool to keep the EIR beads inside of the column and to prevent any loss of the EIR beads during the sample running. The bed length of EIR in the column was about $32 \mathrm{~mm}$. Working solutions containing $\mathrm{U}(\mathrm{VI})$ metal ion, with the concentration exceeding the detection limit, prepared in which the $\mathrm{pH}$ and ionic strength were, respectively, adjusted to 4.5 and $0.1 \mathrm{M}$, using the acetic acid and ammonium acetate solutions, and passed through the column at a known flow rate. After this step, stripping experiments were performed. For this purpose, the column was washed with distilled water $(5 \mathrm{~mL})$, and then, $5 \mathrm{~mL}$ of $0.50 \mathrm{~mol} \mathrm{~L}^{-1} \mathrm{HCl}$ was used to strip U(VI) ions. The desorbed metal ions were analyzed spectrophotometrically by arsenazo III procedure described in Section 2.4.

2.4. Spectrophotometric Arsenazo III Method for the Determination of $U(V I)$. The arsenazo III procedure was utilized for the determination of $\mathrm{U}(\mathrm{VI})$ in solutions [32]. A pH 2.0 buffer solution of $\mathrm{KCl} / \mathrm{HCl}$ was prepared by mixing $8.1 \mathrm{~mL}$ of $0.20 \mathrm{~mol} \mathrm{~L}^{-1} \mathrm{HCl}$ and $41.9 \mathrm{~mL}$ of $0.2 \mathrm{~mol} \mathrm{~L}^{-1} \mathrm{KCl}$ solutions and diluting to $100 \mathrm{~mL}$ with doubly-distilled water. A reagent blank solution containing arsenazo III $1 \%(w / v)$ and buffer solution was freshly prepared before each measurement. Working solutions $(2.5 \mathrm{~mL})$ containing $\mathrm{U}(\mathrm{VI})+0.2 \mathrm{~mL}$ of arsenazo III solution $+2.0 \mathrm{~mL}$ of buffer solution were diluted to $5.0 \mathrm{~mL}$ with distilled water and measured at $653.0 \mathrm{~nm}$.

\section{Results and Discussion}

3.1. Preparation of CAB-Impregnated Resin. Chrome Azurol $\mathrm{B}(\mathrm{CAB})$ is one of the triphenylmethane dyes. It is a dicarboxylic acid with molecular formula of $\mathrm{C}_{23} \mathrm{H}_{16} \mathrm{Cl}_{2} \mathrm{O}_{6}$ (structure is shown in Figure 1). It is slightly soluble in alcohol, soluble in water and gives a reddish orange color solution.

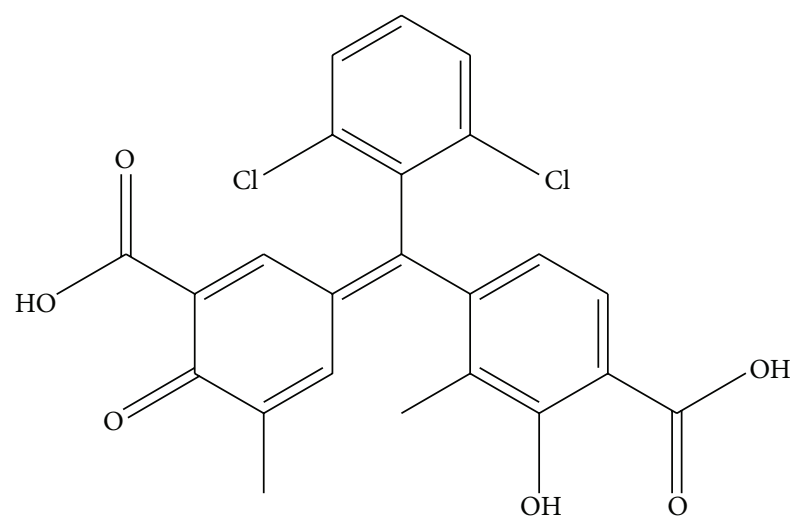

FIgURE 1: Molecular structure of CAB.

This solution turns blue violet at $\mathrm{pH} 13(595 \mathrm{~nm})$. It is a highly sensitive colorimetric reagent for $\mathrm{Fe}(\mathrm{III})$ and is utilized for the determination of the iron content in blood serum at $\mathrm{pH}$ 4.4-5.5 in the presence of cetyltrimethylammonium bromide $[33,34]$. The dye has been utilized for spectrophotometric determination of protein (human serum albumin) using Chrom Azurol B-beryllium(II) complex by manual and flowinjection methods [35]. Also, it has been used as a precipitating reagent, in the presence of a nonionic surfactant (Triton $\mathrm{X}-100$ ), for preparing a membrane and its application to effective collection of iron(III) from homogeneous aqueous solutions [36].

In the current study, $\mathrm{CAB}$ was impregnated onto/into Amberlite XAD-2010 which is used for the preconcentration and isolation of organic materials at trace levels. The resin also has been used as a polymeric support for solid-phase extraction and preconcentration of certain metal ions [3739].

To prepare the appropriate form of the EIR, the impregnation process was carried out at various impregnation ratios ( $\mathrm{g}$ $\mathrm{CAB} / \mathrm{g}$ dry polymer adsorbent). Figure 2 depicts the weight change obtained against the $\mathrm{CAB}$ concentration after washing the EIR with $\mathrm{HCl}$ and distilled water. A maximum weight change $(150.8 \%)$ was found at the concentrations more than $2.50 \mathrm{~g}$ CAB per $200 \mathrm{~mL}$ methanol, which was used for the EIR preparation.

3.2. Stabilizing Extractant Capacity Impregnated on the Polymer. The impregnation of porous matrices leads to the immobilization of the extractant both in pores and in the gel regions of the polymer beads. The impregnating extractant located in the pore volume is weakly retained by the polymer (mainly due to the capillary forces) and can be easily leached out from the freshly prepared EIR samples during the first days of its use (unstable part of EIR capacity). The impregnating extractant taken up by the gel regions of the matrix represents the most stable part of the EIR capacity, which remains practically constant for a long period [40, 41]. Thus, for stabilizing the EIR capacity (the amount of extractant impregnated on the resin), several sorption-desorption cycles were carried out by treating the EIR samples obtained in Figure 2 (EIR sample with maximum impregnated extractant, $1.51 \mathrm{~g} \mathrm{CAB}$ 


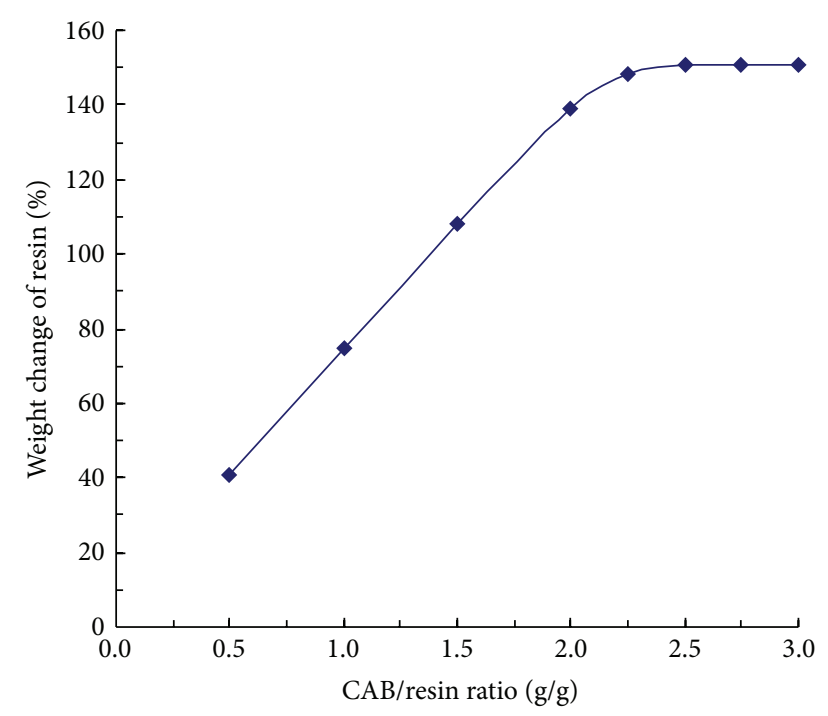

Figure 2: Effect of $\mathrm{CAB} /$ resin ratio (g CAB/g dry resin) on the EIR preparation at the conditions in which portions of $1 \mathrm{~g}$ of the dry polymer beads of Amberlite XAD-2010 were subjected to the impregnation process in $200 \mathrm{~mL}$ methanol.

per $1 \mathrm{~g}$ XAD-2010 resin beads) with $100 \mathrm{~mL}$ aliquots of U(VI) solution having high concentration $(0.01 \mathrm{M}$ at the optimum $\mathrm{pH}$ and ionic strength) and $10 \mathrm{~mL}$ aliquots of $\mathrm{HCl} 2 \mathrm{~mol} \mathrm{~L}^{-1}$ solution as eluent. The sorption-desorption cycles lead to the gradual removal of the extractant molecules from the pore volume of the polymer matrix. The experiments showed that after 13 sorption-desorption cycles the impregnated extractant capacity of EIR was constant. Figure 3 shows the decreasing impregnating extractant capacity (decreasing extractant weight percent impregnated onto $1 \mathrm{~g}$ XAD-2010 resin) on the resin against the number of sorption-desorption cycles. In addition, Figure 3 shows that the impregnating extractant molecules, which were mainly retained due to the capillary forces on the EIR samples, were leached out after 13 cycles of $\mathrm{U}(\mathrm{VI})$ sorption-desorption and, final washing, the EIR samples with $\mathrm{HCl} 4 \mathrm{~mol} \cdot \mathrm{L}^{-1}$ and distilled water. Also, Figure 3 depicts that almost $36.9 \%$ of impregnating extractant capacity immobilized on the untreated EIR, prepared at the maximum impregnating ratio, leach out from the EIR beads by 13 cycles of sorption and desorption. Hence, the maximum weight change is $95.1 \%$ (150.8\% in untreated EIR) which can obtain at the concentrations more than $6.25 \mathrm{~g} \mathrm{CAB}$ per $1 \mathrm{~L}$ methanol.

The chemical stability of the EIR was examined by sequentially suspending a $0.150-\mathrm{g}$ portion of the EIR in different $\mathrm{pHs}$ and shaking for $10 \mathrm{~h}$. After filtering the solutions and rinsing the EIR with distilled water, the released amount of $\mathrm{CAB}$ in solution was examined, spectrophotometrically. The EIR demonstrated high chemical stability since no quantity of $\mathrm{CAB}$ was released into the solutions.

3.3. Effect of $p H$ and Ionic Strength on U(VI) Sorption onto/into New EIR. Initially, these experiments were carried out to select the optimum sorption medium. Buffer solutions of $\mathrm{pH}$

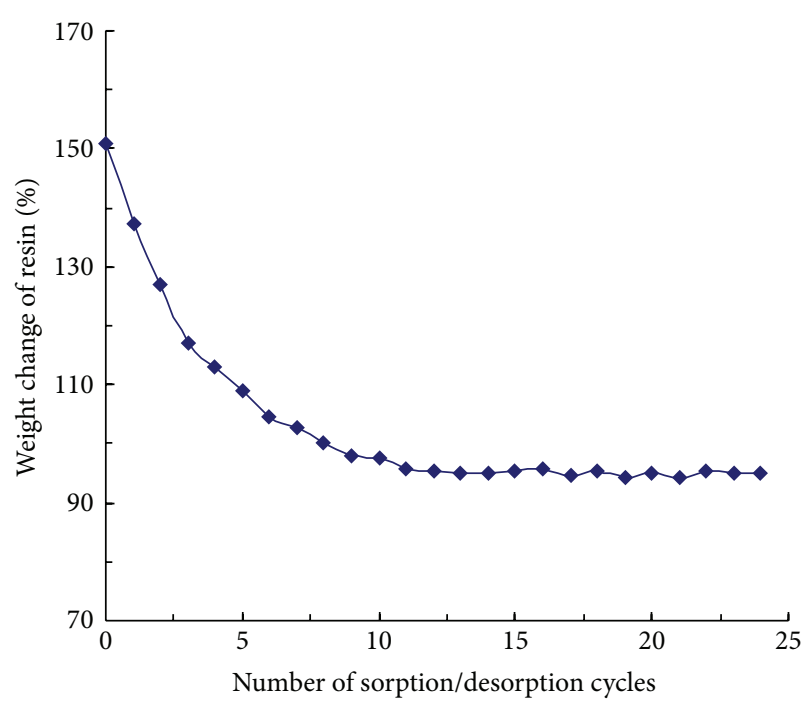

FIGURE 3: Stabilizing impregnating extractant capacity on the resin weight change after stabilizing extractant content of EIR beads by carrying out sorption-desorption cycles.

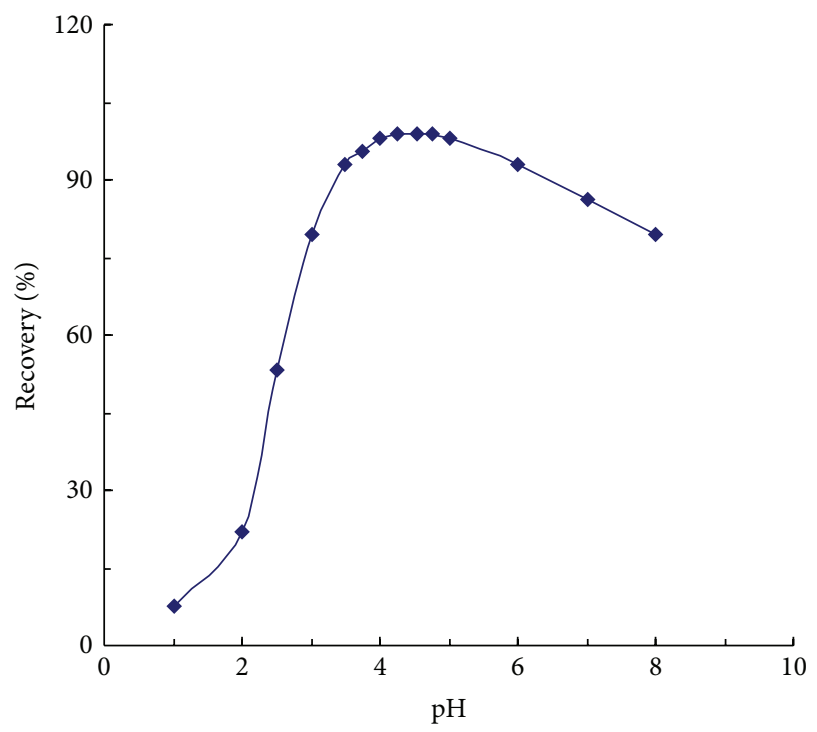

FIgURE 4: Effect of $\mathrm{pH}$ on the recovery percent of $\mathrm{U}(\mathrm{VI})$ using $100 \mathrm{~mL}$ of model solutions of $100 \mu \mathrm{g} \mathrm{L}{ }^{-1} \mathrm{U}(\mathrm{VI})$ containing $0.150 \mathrm{~g}$ of the EIR at $298 \pm 1 \mathrm{~K}$.

1-8 were used to measure the $\mathrm{pH}$ effect on the sorption of $\mathrm{U}(\mathrm{VI})$ ions. The concentration and volume of $\mathrm{U}(\mathrm{VI})$ solutions used for this study were $100 \mu \mathrm{g} \mathrm{L}^{-1}$ and $100 \mathrm{~mL}$ at $298 \pm 1 \mathrm{~K}$. The adsorbent dosage was $0.150 \mathrm{~g}$ of dry EIR at maximum impregnation ratio (0.95 g CAB/g dry XAD-2010). The shaker speed was $180 \mathrm{rpm}$ and time contact was about $30 \mathrm{~min}$. The results are shown in Figure 4. The sorption increases with increasing $\mathrm{pH}$ of sorptive solution and attains a maximum value at $\mathrm{pH} 4.2-4.7$. This indicates that the sorption process involves the release of $\mathrm{H}^{+}$ions to allow the firm complexation of $\mathrm{U}(\mathrm{VI})$ ions to $\mathrm{CAB} / \mathrm{XAD}-2010$ at the optimum $\mathrm{pH}$. At the low $\mathrm{pHs}$, the release of $\mathrm{H}^{+}$ions was not efficient because of 
the low acidic dissociation constant of Chrome Azurol B. However, the amount of metal ions sorbed decreased when $\mathrm{pH}$ was very high. This may be due to the hydrolysis of the $\mathrm{U}(\mathrm{VI})$ metal ions in high $\mathrm{pH}$ solutions [25]. Because of these considerations, the buffer $\mathrm{pH}$ of 4.5 was selected for subsequent investigations.

The effect of ionic strength on the sorption process was also studied at the presence of sodium nitrate within the concentration range $0.01-0.40 \mathrm{~mol} \cdot \mathrm{L}^{-1}$. For this purpose, $100 \mathrm{~mL}$ aliquots of $\mathrm{U}(\mathrm{VI})$ solution $(\mathrm{pH} 4.5$ ) having concentration of $100 \mu \mathrm{g} \mathrm{L}^{-1} \mathrm{U}(\mathrm{VI})$ were treated with $0.150 \mathrm{-g}$ portions of EIR at $298 \pm 1 \mathrm{~K}$ and different ionic strengths. It was found that the sorption efficiencies were diminished at the ionic strength values greater than $0.3 \mathrm{~mol} \mathrm{~L}^{-1}$. This behavior is almost predictable since by increasing the ionic strength the salt effect is enhanced and, consequently, the sorption process is inhibited. Hence, the ionic strength did not exceed $0.3 \mathrm{~mol} \cdot \mathrm{L}^{-1}$ at subsequent investigations.

3.4. Effect of Shaking Speed on U(VI) Ions Sorption. Sorption of metal ions as a function of shaking speed was studied in the range of $30-200 \mathrm{rpm}$. The aliquots of $100 \mathrm{~mL}$ of $\mathrm{U}(\mathrm{VI})$ solution having concentration of $100 \mu \mathrm{gL}^{-1}$ were treated with 0.150 -g portions of EIR at the optimum conditions. It was found that percent sorption increases with increasing shaking speed and attains a maximum sorption at $180 \mathrm{rpm}$. For further studies, shaking speed of $180 \mathrm{rpm}$ was employed for $\mathrm{U}(\mathrm{VI})$ ions sorption in batch experiments.

3.5. Effect of Contact Time on U(VI) Ions Sorption. The sorption of $\mathrm{U}(\mathrm{VI})$ ions onto/into EIR was studied as a function of shaking time. Sorption process was very rapid and $t_{1 / 2}$ is smaller than $6 \mathrm{~min}$. Also, $25 \mathrm{~min}$ was found to be sufficient time to attain maximum sorption of $\mathrm{U}(\mathrm{VI})$ ions onto/into new EIR. The fast kinetics of resin-metal interaction at optimum $\mathrm{pH}$ (4.5) may be attributed to better accessibility of the chelating sites of the modified resin for metal ions. Beyond $25 \mathrm{~min}$, no increase in percent sorption was observed; therefore, for further investigations $25 \mathrm{~min}$ agitation time was applied. Also, this fast equilibration rate may be related to the large surface area and pore size of Amberlite XAD-2010. Accordingly, the EIR can be applied to column separation and preconcentration of $\mathrm{U}(\mathrm{VI})$ ions.

3.6. Sorption Capacity. The sorption capacity of the Amberlite XAD-2010 resin impregnated with CAB for the extraction of uranium was also determined. Increasing amounts of uranium were added to $0.150 \mathrm{~g}$ of impregnated resin. The sorption curve (not shown) appears to be linear in the range of $1.5 \times 10^{-6}-1.5 \times 10^{-4} \mathrm{~mol}$ of $\mathrm{U}(\mathrm{VI})$ per $150.0 \mathrm{~mL}$ and it reaches a plateau at maximum sorption capacity, that is, $0.632 \mathrm{mmol}$ Uranium/g EIR at $\mathrm{pH}$ 4.5. To compare the sorption capacity of the EIR with that of nonimpregnated Amberlite XAD-2010, the sorption capacity of the nonimpregnated Amberlite XAD-2010 resin, also, was determined at the above mentioned concentrations. The results showed that the sorption capacity of the nonimpregnated Amberlite XAD2010 resin was negligible. This indicates that CAB/XAD-2010
TABLE 1: Effect of type and concentration of eluting acid on recovery of $\mathrm{U}(\mathrm{VI})$ ions $(n=3)$.

\begin{tabular}{lccc}
\hline Eluent & Volume $(\mathrm{mL})$ & Concentration $(\mathrm{M})$ & Recovery $(\%)$ \\
\hline $\mathrm{HNO}_{3}$ & 10 & 0.5 & 83.1 \\
$\mathrm{HNO}_{3}$ & 10 & 1.0 & 87.5 \\
$\mathrm{HCl}$ & 10 & 1.0 & 98.9 \\
$\mathrm{HCl}$ & 10 & 0.5 & 98.9 \\
$\mathrm{HCl}$ & 5 & 1.0 & 98.8 \\
$\mathrm{HCl}$ & 5 & 0.5 & 98.9 \\
$\mathrm{HCl}$ & 5 & 0.4 & 94.6 \\
$\mathrm{H}_{2} \mathrm{SO}_{4}$ & 10 & 0.5 & 92.3 \\
$\mathrm{H}_{2} \mathrm{SO}_{4}$ & 5 & 1.0 & 94.0 \\
$\mathrm{H}_{2} \mathrm{SO}_{4}$ & 5 & 2.0 & 93.8 \\
$\mathrm{HAC}$ & 10 & 0.5 & 38.1 \\
$\mathrm{HAC}$ & 10 & 1.0 & 40.8 \\
\hline
\end{tabular}

resin could be used as a good sorbent for preconcentration of uranium in the trace concentration range.

3.7. Desorption Studies. Various mineral acids were studied as eluent to investigate their efficiency for desorbing and separating U(VI) ions from the EIR, using different volumes and concentrations of each eluent. The results were summarized in Table 1. It was found that $5 \mathrm{~mL}$ of $0.50 \mathrm{~mol} \cdot \mathrm{L}^{-1}$ $\mathrm{HCl}$ was sufficient for quantitative recovery of $\mathrm{U}(\mathrm{VI})$ ions. Therefore, $5 \mathrm{~mL}$ of $0.50 \mathrm{~mol} \cdot \mathrm{L}^{-1} \mathrm{HCl}$ specified as the eluent for desorption of metal U(VI) ions from EIR and was used for the subsequent studies.

3.8. Adsorption Equilibrium Studies. Equilibrium properties of adsorption systems are usually expressed as adsorption isotherms. Adsorption isotherm is a function that correlates the amount of metal ion adsorbed per unit weight of the adsorbent, $q_{e}\left(\mathrm{mg} \mathrm{g}^{-1}\right)$, and the equilibrium concentration of metal ion in bulk solution, $C_{e}\left(\mathrm{mg} \cdot \mathrm{L}^{-1}\right)$, at a given temperature. The isotherm function deals with the adsorption model, which is an important physicochemical feature for the description of how metal ions interact with active sites in the adsorbent surface. The adsorption model is critical in evaluating the basic characteristics of a good adsorbent. In an EIR system, the adsorption process results in the sorption of metal ions from the solution onto the polymeric matrix until the remaining metal ions in the solution are in dynamic equilibrium with metal ions on the EIR surface. At equilibrium there is a finite distribution of the metal ion between the solution and EIR phase, which can be described by many isotherms and adsorption models that can be used to fit the observed experimental data and determining the model parameters. Three isotherm equations have been tested in the present study, namely, Langmuir [42], Tempkin and Pyzhev [43], and Freundlich [44]. These isotherm equations are represented by the following.

Langmuir isotherm:

$$
q_{e}=\frac{q_{\mathrm{max}} b C_{e}}{1+b C_{e}},
$$




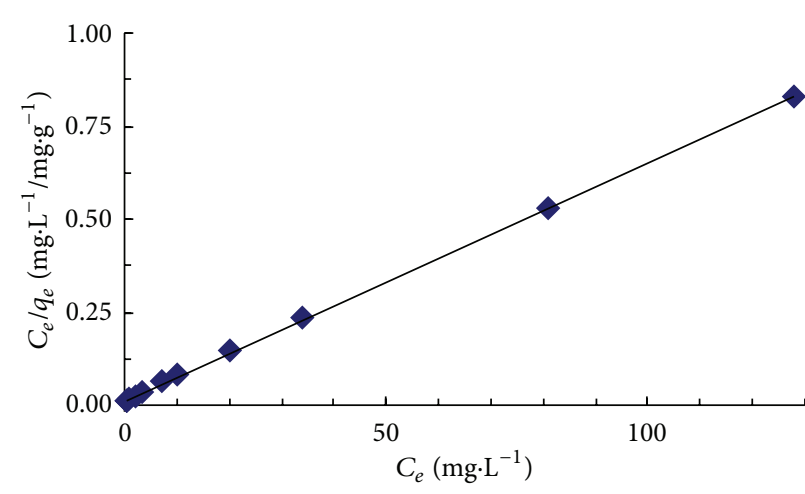

(a)

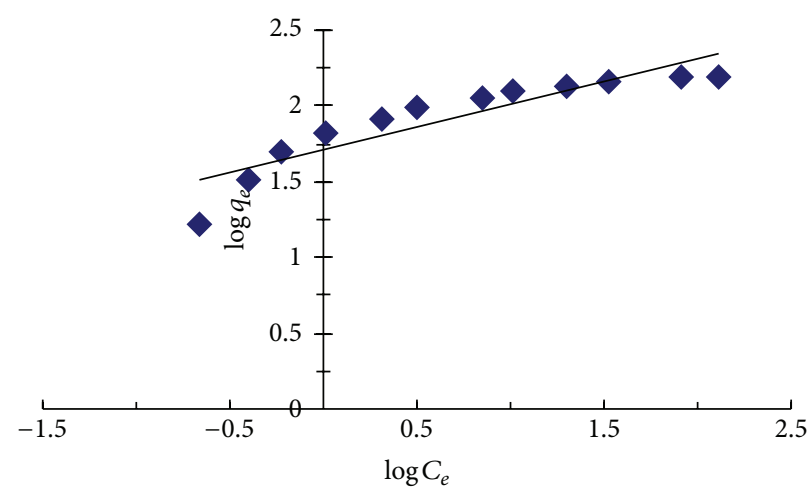

(b)

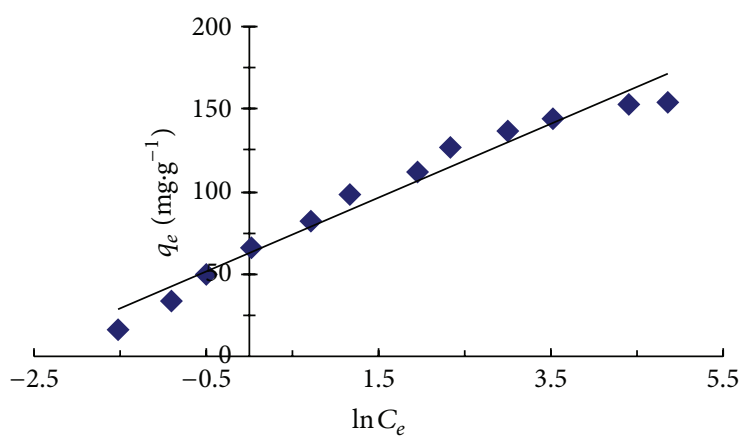

(c)

FIGURE 5: Langmuir (a), Freundlich (b), and Tempkin (c) adsorption isotherms for U(VI) adsorption by EIR (pH 4.5 and temperature $298 \mathrm{~K}$ ).

freundlich isotherm:

$$
q_{e}=K_{F} C_{e}^{1 / n}
$$

tempkin isotherm:

$$
q_{e}=\frac{\mathrm{RT}}{b}\left(\ln K_{T} C_{e}\right)
$$

The linear form of the Langmuir, Freundlich and Tempkin isotherms can be expressed by (5)-(7), respectively. Consider

$$
\begin{gathered}
\frac{C_{e}}{q_{e}}=\frac{C_{e}}{q_{\max }}+\frac{1}{b q_{\max }}, \\
\log q_{e}=\log K_{f}+\frac{1}{n} \log C_{e}, \\
q_{e}=B \ln K_{T}+B \ln C_{e},
\end{gathered}
$$

where $C_{e}$ is the equilibrium concentration $\left(\mathrm{mg} \cdot \mathrm{L}^{-1}\right), q_{e}$ is the adsorption capacity at equilibrium $\left(\mathrm{mg} \cdot \mathrm{g}^{-1}\right), q_{\max }\left(\mathrm{mg} \cdot \mathrm{g}^{-1}\right)$ represents the maximum adsorption capacity, $b\left(\mathrm{~L} \cdot \mathrm{mg}^{-1}\right)$ relates the energy of adsorption, $K_{f}$ indicates relative adsorption capacity $\left(\mathrm{mg}^{1-(1 / n)} \cdot \mathrm{L}^{1 / n} \cdot \mathrm{g}^{-1}\right), n$ is an empirical parameter related to the intensity of adsorption, $B$ is the Tempkin constant related to the heat of adsorption $(B=\mathrm{RT} / b)$, and $K_{T}$ is the equilibrium binding constant $\left(\mathrm{L} \cdot \mathrm{g}^{-1}\right)$ corresponding to the maximum binding energy.
TABLe 2: Parameters of the Langmuir and Freundlich isotherm models for the adsorption of $\mathrm{U}(\mathrm{II})$ ion by $\mathrm{CAB}$-impregnated $\mathrm{XAD}$ 2010 .

\begin{tabular}{lc}
\hline Isotherm model & Magnitude \\
\hline Langmuir & \\
$\quad q_{\max }\left(\mathrm{mg} \cdot \mathrm{g}^{-1}\right)$ & 156.2 \\
$\quad b\left(\mathrm{~L} \cdot \mathrm{mg}^{-1}\right)$ & $48.85 \times 10^{-2}$ \\
$\quad R^{2}$ & 0.9998 \\
Freundlich & \\
$\quad K_{F}\left(\mathrm{mg}^{1-(1 / n)} \cdot \mathrm{L}^{1 / n} \cdot \mathrm{g}^{-1}\right)$ & 51.02 \\
$n$ & 3.323 \\
$R^{2}$ & 0.8181 \\
Tempkin & \\
$B$ & 22.41 \\
$K_{T}\left(\mathrm{~L} \cdot \mathrm{g}^{-1}\right)$ & 16.013 \\
$R^{2}$ & 0.9641 \\
\hline
\end{tabular}

The isotherm plots were drawn using (5)-(7) and the resulted plots are depicted in Figure 5. The values of isotherms parameters are presented in Table 2. As seen from Table 2 and Figure 5, the Langmuir isotherm shows a higher correlation coefficient, and a better fit, to adsorption data than the other isotherm equations. This explains the suitability of Langmuir model for describing the adsorption equilibrium of U(VI) onto CAB/XAD-2010. 
The Langmuir adsorption isotherm is based on the assumption that all adsorption sites are equivalent and that adsorption in an active site is independent of whether the adjacent sites are occupied or not. The fact that the Langmuir isotherm fits the experimental data very well may be due to homogenous distribution of extractant molecules, or active chelating sites, on the polymeric surface, since the Langmuir equation assumes that the adsorbent surface is homogenous [28].

\subsection{Dynamic Sorption}

3.9.1. Effect of Column Flow Rate on Sorption and Desorption. The effect of column flow rate on the sorption of U(VI) was separately studied in the range of $1-18 \mathrm{~mL} \mathrm{~min}^{-1}$ using $1 \mathrm{~L}$ of solution with $\mathrm{U}(\mathrm{VI})$ concentration of $10 \mu \mathrm{g} \mathrm{L}^{-1}$ at the $\mathrm{pH}$ chosen for maximum sorption for both metal ions. The

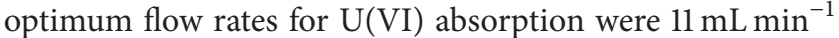
(Figure 6). Therefore, a flow rate of $11 \mathrm{~mL} \mathrm{~min}^{-1}$ was selected for further studies in the preconcentration of $\mathrm{U}(\mathrm{VI})$ ions. Optimum column desorption flow rates were investigated using $5 \mathrm{~mL}$ of the recommended eluent solution, $0.50 \mathrm{~mol} \cdot \mathrm{L}^{-1}$ $\mathrm{HCl}$, after loading the column with $1 \mathrm{~L}$ of sample solutions with concentration of $10 \mu \mathrm{g} \mathrm{L}^{-1}$ with respect to U(VI) followed by rinsing the column with $5 \mathrm{~mL}$ double-distilled water. Figure 6 shows that optimum flow rate for desorpting $\mathrm{U}(\mathrm{VI})$ is $0.5 \mathrm{~mL} \mathrm{~min}^{-1}$.

3.9.2. Effect of Sample Volume and Preconcentration Factor. Since the concentrations of uranium in real samples are low, the amounts of uranium in these samples should be taken into smaller volumes for high preconcentration factor. Therefore, the limit of preconcentration was determined by increasing the dilution of the $\mathrm{U}(\mathrm{VI})$ ion in solution keeping the total amount of loaded $\mathrm{U}(\mathrm{VI})$ ion at $10 \mu \mathrm{g}$. Adsorbed metal ions were stripped (desorbed) with the optimum concentration and volume of specified eluent. Complete recovery can be carried out from solutions with volumes up to $1600 \mathrm{~mL}$ with a recovery of $>98 \%$, yielding in the preconcentration factor of 160. Thus, for convenience, the sample volume of $1500 \mathrm{~mL}$ (the preconcentration factor of 150) was chosen for the column-mode separation and preconcentration of $\mathrm{U}(\mathrm{VI})$ ions.

In order to determine the detection limit of the proposed dynamic method, $1500 \mathrm{~mL}$ aliquots of blank solutions were adjusted to optimized conditions and passed through the column. After eluting the column and determining uranium, the detection limit of the procedure (based on $3 \delta$ of the blank solution, $n=8$ ) was found to be $5.0 \times 10^{-10} \mathrm{~mol} \cdot \mathrm{L}^{-1}$ $\left(0.12 \mu \mathrm{g} \cdot \mathrm{L}^{-1}\right)$.

3.10. Effect of Foreign Ions. The performance of the technique for the quantitative separation and preconcentration of $\mathrm{U}(\mathrm{VI})$ ions in the presence of foreign cations and anions was investigated by measuring the recovery (\%) of U(VI) under optimized conditions. For this purpose, $1500 \mathrm{~mL}$ aliquots of $\mathrm{U}(\mathrm{VI})$ solution with concentration of $7.0 \mu \mathrm{g} \mathrm{L}{ }^{-1}$ were taken with different amounts of foreign ions and the recommended

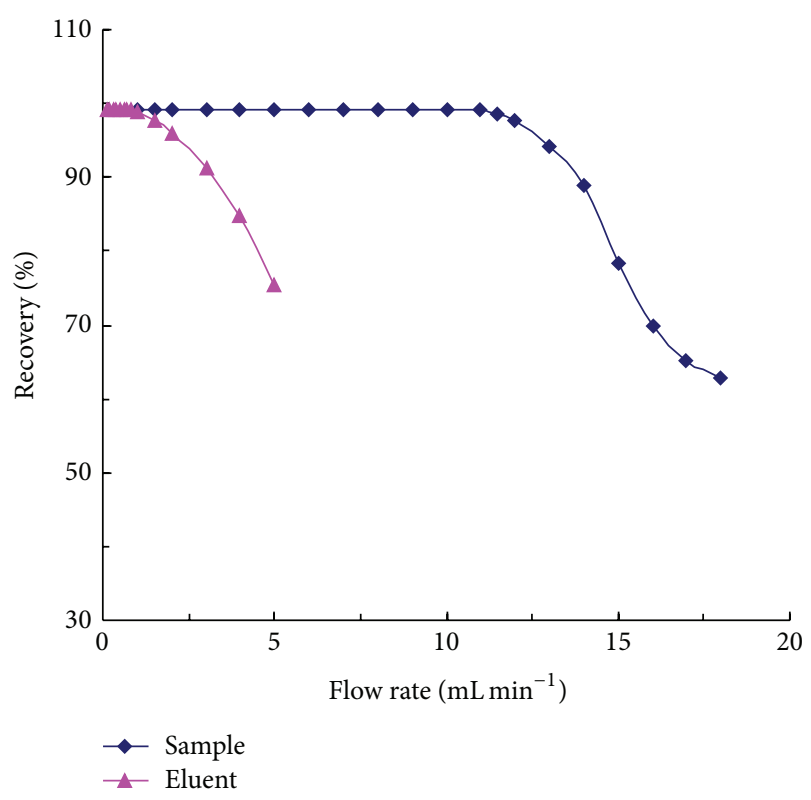

Figure 6: Effect of sample and eluent flow rates on the recovery of $\mathrm{U}(\mathrm{VI})$ using $1 \mathrm{~L}$ of model solution of $10 \mu \mathrm{g} \mathrm{L} \mathrm{L}^{-1} \mathrm{U}(\mathrm{VI})$, eluting with $5 \mathrm{~mL}$ eluent solution of $0.50 \mathrm{M} \mathrm{HCl}$. The data presented are the average of five experiments.

TABLE 3: Effect of foreign ions on the determination of $7.0 \mu \mathrm{g}$ of $\mathrm{U}(\mathrm{VI})$ in $1,500-\mathrm{mL}$ aliquots of the solution.

\begin{tabular}{lc}
\hline Foreign ion & Tolerance ratio \\
\hline $\mathrm{Na}^{+}, \mathrm{K}^{+}, \mathrm{Mg}^{2+}, \mathrm{Ca}^{2+}, \mathrm{Ba}^{2+}, \mathrm{Zn}^{2+}, \mathrm{NH}_{4}{ }^{+}, \mathrm{Cl}^{-}$, & 5000 \\
$\mathrm{I}^{-}, \mathrm{Co}^{2+}, \mathrm{Sr}^{2+}$ & 3000 \\
$\mathrm{SO}_{4}^{2-}, \mathrm{Pb}^{2+}, \mathrm{CrO}_{4}{ }^{2-}, \mathrm{Mn}^{2+}, \mathrm{Cd}^{2+}$ & 1000 \\
$\mathrm{MoO}_{4}{ }^{2-}$, Citrate & 500 \\
$\mathrm{Ag}^{+}$ & $300^{\mathrm{a}}$ \\
$\mathrm{Ni}^{2+}$ & 200 \\
$\mathrm{Ce}^{3+}$ & $200^{\mathrm{b}}$ \\
$\mathrm{Th}^{4+}$ & $150^{\mathrm{a}}$ \\
$\mathrm{Cu}^{2+}$ & 100 \\
$\mathrm{Zr}^{4+}, \mathrm{La}^{3+}$ & 80 \\
$\mathrm{Fe}^{3+}$ & 5 \\
$\mathrm{Ni}^{2+}$ & 2 \\
$\mathrm{Cu}^{2+}$ & 1 \\
$\mathrm{Th}^{4+}$ & \\
\hline
\end{tabular}

${ }^{\mathrm{a}}$ In the presence of potassium cyanide $\left(1 \times 10^{-3} \mathrm{M}\right)$.

${ }^{b}$ In the presence of EDTA $\left(1 \times 10^{-3} \mathrm{M}\right)$.

column-mode procedure was followed. The tolerance limit was defined as the highest ratio of foreign ions that produced an error not exceeding $\pm 5 \%$ in the determination of $\mathrm{U}(\mathrm{VI})$ ions by the combination of the column solid-phase extraction and arsenazo III method, as described above. The serious interference from $\mathrm{Ni}(\mathrm{II})$ and $\mathrm{Cu}(\mathrm{II})$ was avoided by masking with potassium cyanide [45], whereas the interference due to $\mathrm{Th}(\mathrm{VI})$ was removed by adding EDTA [46]. The tolerated amounts of the foreign ions are given in Table 3 . The results 
TABLE 4: Application of the proposed method for the determination of U(VI) in 1500 aliquots of environmental water samples.

\begin{tabular}{lccc}
\hline Sample & Added $\left(\mu \mathrm{g} \mathrm{L}^{-1}\right)$ & Found $\left(\mu \mathrm{g} \mathrm{L}^{-1}\right)$ & Recovery $(\%)$ \\
\hline Spring water & 0.0 & $1.4(2.9)^{\mathrm{a}}$ & - \\
(Ghazi Spring) & 2.0 & $3.3(2.6)$ & 97.0 \\
& 5.0 & $6.2(2.7)$ & 96.9 \\
& 10.0 & $11.0(2.6)$ & 96.5 \\
\hline & 20.0 & $20.7(2.6)$ & 96.7 \\
River water & 0.0 & $5.7(2.3)$ & - \\
(Shesh-Taraz) & 2.0 & $7.8(2.2)$ & 101.3 \\
& 10.0 & $25.8(2.2)$ & 100.6 \\
& 20.0 & $35.6(2.0)$ & 100.7 \\
Well water & 30.0 & - & 99.7 \\
(Argha) & 0.00 & $9.8(1.9)$ & 98.0 \\
& 10.00 & $19.6(1.7)$ & 98.0 \\
& 20.00 & $29.3(1.3)$ & 97.7 \\
\hline
\end{tabular}

${ }^{a} \mathrm{RSD}$ of five replicate measurements.

TABLE 5: Results of the accuracy test of proposed method for U(VI) determination in two geological standard reference materials.

\begin{tabular}{lccc}
\hline Samples & U(VI) content $\left(\mu \mathrm{g} \mathrm{g}^{-1}\right)$ & Found $\left(\mu \mathrm{g} \mathrm{g}^{-1}\right)$ & Recovery $(\%)$ \\
\hline${\mathrm{JG}-1 \mathrm{a}^{\mathrm{a}}}^{\mathrm{a}}$ & 4.7 & $4.63(3.1)^{\mathrm{b}}$ & 98.6 \\
$\mathrm{JR}^{\mathrm{a}}$ & 8.9 & $8.81(3.0)^{\mathrm{b}}$ & 99.0 \\
\hline
\end{tabular}

"The treatments were carried out on $0.5 \mathrm{~g}$ of the sample.

${ }^{\mathrm{b}} \mathrm{RSD}$ of five replicate measurements.

show that the proposed method can be adequately applied for the selective determination of U(VI) in the aqueous samples.

3.11. Application of Proposed Method for Natural Water Samples. The proposed method was applied to the determination of U(VI) in natural water samples including spring, well, and river water samples that they were isokinetically collected in polyethylene bottles from different areas of Kashmar, a city in Iran, Khorasan Razavi province. These water samples were passed through a membrane filter with a pore size of $0.45 \mathrm{~mm}$ to remove their particulates and then $\mathrm{pH}$ was brought to 4.5. By adding sufficient amounts of potassium cyanide and EDTA, as masking agents, their concentration reached up to $1.0 \times 10^{-3} \mathrm{M}$. Then, $1500 \mathrm{~mL}$ aliquots of the samples were subjected to the recommended dynamic procedure. A recovery test was also performed by determining the spiked amounts of U(VI) to the samples. The obtained results are summarized in Table 4. As observed from the results, the recoveries for the various amounts spiked to the sample solutions were in the range 96.1-101.3\%, which reflect the suitability of the present EIR as a preconcentration tool before actual measurement of U(VI) in contaminated water samples using arsenazo III method.

3.12. Application of Proposed Method for Standard Geological Samples. For testing the accuracy of the measurements, two model solutions were prepared just according to the composition of JG-1a and JR-1 (Geological Survey of Japan reference samples) by precisely following the literature considerations [47]. The results of the expected and found values are detailed in Table 5. The agreement between found and expected values demonstrated that the described method was accurate for trace analysis of $\mathrm{U}(\mathrm{VI})$ in the complex matrices.

\section{Conclusions}

Chrome Azurol B-impregnated XAD-2010 resin beads were prepared and used for solid-phase extraction and preconcentration of $U(V I)$ in various environmental water samples. The proposed procedure for the determination of trace amounts of $\mathrm{U}(\mathrm{VI})$ ions combines preconcentration of the analyte with spectrophotometric measurement with the arsenazo III procedure. The sorption equilibrium data were analyzed using widely used isotherm models. The Langmuir isotherm gave the best fit of the experimental equilibrium data. Thus, the distribution of extractant molecules on the polymeric surface is homogenous, and the adsorption process is monolayer. The optimized experimental parameters for the new solid-phase extraction system have been summarized in Table 6. The new EIR benefits from high sorption capacities and excellent selectivity. Also the proposed preconcentration method was simple and rapid, and it is a convenient and low cost one. The new EIR had excellent selectivity for U(VI) in the complex matrixes of geological samples, and the matrix effects with the method were reasonably tolerable. The system was also successful in pre-concentrating metal ions from large sample 
TABLE 6: Optimized experimental parameters for separation and pre-concentration of U(VI) ions by CAB-impregnated XAD-2010.

\begin{tabular}{lc}
\hline Experimental parameter & Optimum magnitude \\
\hline Batch parameters & \\
$\mathrm{pH}$ & $4.2-4.7$ \\
Ionic strength & $0.01-0.30 \mathrm{~mol} \cdot \mathrm{L}^{-1}$ \\
Shaking speed & $180 \mathrm{rpm}$ \\
Contact time & $25 \mathrm{~min}$ \\
$t_{1 / 2}$ & $6 \mathrm{~min}$ \\
Capacity & $0.632 \mathrm{mmol} \cdot \mathrm{g}^{-1}$ \\
Concentration of eluent $(\mathrm{HCl})$ & $0.50 \mathrm{M}$ \\
Volume of eluent & $5 \mathrm{~mL}$ \\
\hline Dynamic parameters & $11 \mathrm{~mL} \cdot \mathrm{min}{ }^{-1}$ \\
Sample flow rate & $0.5 \mathrm{~mL} \cdot \mathrm{min}{ }^{-1}$ \\
Eluent flow rate & $1600 \mathrm{~mL}$ \\
Sample volume & $5.0 \times 10^{-10} \mathrm{~mol} \cdot \mathrm{L}^{-1}$ \\
LOD &
\end{tabular}

volume. Overall, some of the practical benefits of the new method include its capacity, selectivity, good detection limit, high preconcentration factor, low cost, speed, convenience, and ease of regeneration of the EIR.

\section{Acknowledgments}

The authors wish to thank Dr. M. J. Mosavi (the president of Islamic Azad University-Kashmar branch, Kashmar, Iran) for sincere support and Professor M.S. Hosseini (Birjand University, Birjand, Iran) for a great help during the experimental works. Also, they acknowledge the financial and technical support provided by the Research Center of Islamic Azad University-Kashmar branch, Kashmar, Iran.

\section{References}

[1] WHO, Guidelines for Drinking Water Quality, WHO, Geneva, Switzerland, 2nd edition, Addendum to vol. 2, Health Criteria and Other Supporting Information, WHO/EOS/98. 1, 1998.

[2] T. P. Rao, P. Metilda, and J. M. Gladis, "Preconcentration techniques for uranium(VI) and thorium(IV) prior to analytical determination: an overview," Talanta, vol. 68 , no. 4, pp. 10471064, 2006.

[3] R. K. Singhal, U. Narayanan, R. Karpe, A. Kumar, A. Ranade, and V. Ramachandran, "Selective separation of iron from uranium in quantitative determination of traces of uranium by alpha spectrometry in soil/sediment sample," Applied Radiation and Isotopes, vol. 67, no. 4, pp. 501-505, 2009.

[4] A. R. Byrne and L. Benedik, "An internal standard method in a spectrometric determination of uranium and thorium radioisotopes using instrumental neutron activation analysis," Analytical Chemistry, vol. 69, no. 6, pp. 996-999, 1997.

[5] J. S. Santos, L. S. G. Teixeira, R. G. O. Araújo, A. P. Fernandes, M. G. A. Korn, and S. L. C. Ferreira, "Optimization of the operating conditions using factorial designs for determination of uranium by inductively coupled plasma optical emission spectrometry," Microchemical Journal, vol. 97, no. 2, pp. 113-117, 2011.
[6] F. A. Aydin and M. Soylak, "Solid phase extraction and preconcentration of uranium(VI) and thorium(IV) on Duolite XAD761 prior to their inductively coupled plasma mass spectrometric determination," Talanta, vol. 72, no. 1, pp. 187-192, 2007.

[7] M. S. Hosseini, H. Raissi, and H. R. Yavari, "Synergistic flotation of $\mathrm{U}(\mathrm{VI})$-alizarin complex with some diamines followed by spectrophotometric determination of $\mathrm{U}(\mathrm{VI})$ using $4,4^{\prime}$ diaminophenylmethane," Analytica Chimica Acta, vol. 559, no. 2, pp. 181-185, 2006.

[8] D. Prabhakaran and M. S. Subramanian, "Selective extraction and sequential separation of actinide and transition ions using AXAD-16-BTBED polymeric sorbent," Reactive and Functional Polymers, vol. 57, no. 2-3, pp. 147-155, 2003.

[9] J. Avivar, L. Ferrer, M. Casas, and V. Cerdà, "Smart thorium and uranium determination exploiting renewable solid-phase extraction applied to environmental samples in a wide concentration range," Analytical and Bioanalytical Chemistry, vol. 400, no. 10, pp. 3585-3594, 2011.

[10] A. M. Starvin and T. P. Rao, "Solid phase extractive preconcentration of uranium(VI) onto diarylazobisphenol modified activated carbon," Talanta, vol. 63, no. 2, pp. 225-232, 2004.

[11] P. Metilda, K. Sanghamitra, J. Mary Gladis, G. R. K. Naidu, and T. Prasada Rao, "Amberlite XAD-4 functionalized with succinic acid for the solid phase extractive preconcentration and separation of uranium(VI)," Talanta, vol. 65, no. 1, pp. 192200, 2005.

[12] M. S. Hosseini and A. Hosseini-Bandegharaei, "Comparison of sorption behavior of Th(IV) and U(VI) on modified impregnated resin containing quinizarin with that conventional prepared impregnated resin," Journal of Hazardous Materials, vol. 190, no. 1-3, pp. 755-765, 2011.

[13] A. Hosseini-Bandegharaei, M. S. Hosseini, Y. Jalalabadi et al., "A novel extractant-impregnated resin containing carminic acid for selective separation and pre-concentration of uranium(VI) and thorium(IV)," International Journal of Environmental Analytical Chemistry, vol. 93, pp. 108-124, 2013.

[14] K. Pyrzyñska and M. Trojanowicz, "Functionalized cellulose sorbents for preconcentration of trace metals in environmental analysis," Critical Reviews in Analytical Chemistry, vol. 29, no. 4, pp. 313-321, 1999.

[15] J. M. Gladis and T. Prasada Rao, "Solid phase extractive preconcentration of uranium on to 5,7-dichloroquinoline-8-ol modified naphthalene," Analytical Letters, vol. 35, no. 3, pp. 501$515,2002$.

[16] M. Ghaedi, K. Niknam, S. Zamani, H. Abasi Larki, M. Roosta, and M. Soylak, "Silica chemically bonded N-propyl kriptofix 21 and 22 with immobilized palladium nanoparticles for solid phase extraction and preconcentration of some metal ions," Materials Science and Engineering C, vol. 33, pp. 3180-3189, 2013.

[17] M. Ghaedi, K. Mortazavi, M. Montazerozohori, A. Shokrollahi, and M. Soylak, "Flame atomic absorption spectrometric (FAAS) determination of copper, iron and zinc in food samples after solid-phase extraction on Schiff base-modified duolite XAD 761," Materials Science and Engineering C, vol. 33, pp. 3180-3189, 2013.

[18] V. Dharmendra and A. Krishnaiah, "Preconcentration, separation and determination of $\mathrm{Pb}(\mathrm{II})$ and $\mathrm{Cd}(\mathrm{II})$ in water samples with inductively coupled plasma atomic emission spectrometer (ICP-AES) using 3-(2-Hydroxyphenyl)-1H-1, 2, 4-triazole5(4H)-thione (HTT)," Journal of Chemistry, vol. 2013, Article ID 658132, 20 pages, 2013. 
[19] R. Navarro, I. Saucedo, A. Núñez, M. Ávila, and E. Guibal, "Cadmium extraction from hydrochloric acid solutions using Amberlite XAD-7 impregnated with Cyanex 921 (tri-octyl phosphine oxide)," Reactive and Functional Polymers, vol. 68, no. 2, pp. 557-571, 2008.

[20] I. Narin and M. Soylak, "The uses of 1-(2-pyridylazo) 2-naphtol (PAN) impregnated Ambersorb 563 resin on the solid phase extraction of traces heavy metal ions and their determinations by atomic absorption spectrometry," Talanta, vol. 60, no. 1, pp. 215-221, 2003.

[21] M. H. A. Melo, S. L. C. Ferreira, and R. E. Santelli, "Determination of cadmium by FAAS after on-line enrichment using a mini column packed with Amberlite XAD-2 loaded with TAM," Microchemical Journal, vol. 65, no. 1, pp. 59-65, 2000.

[22] J. L. Cortina and N. Miralles, "Kinetic studies on heavy metal ions removal by impregnated resins containing di- $(2,4,4-$ trymethylpentyl) phosphinic acid," Solvent Extraction and Ion Exchange, vol. 15, no. 6, pp. 1067-1083, 1997.

[23] N. Demirel, M. Merdivan, N. Pirinccioglu, and C. Hamamci, "Thorium(IV) and uranium(VI) sorption studies on octacarboxymethyl-C-methylcalix[4] resorcinarene impregnated on a polymeric support," Analytica Chimica Acta, vol. 485, no. 2, pp. 213-219, 2003.

[24] S. Seyhan, M. Merdivan, and N. Demirel, "Use of o-phenylene dioxydiacetic acid impregnated in Amberlite XAD resin for separation and preconcentration of uranium(VI) and thorium(IV)," Journal of Hazardous Materials, vol. 152, no. 1, pp. 79-84, 2008.

[25] E. Metwally, "Kinetic studies for sorption of some metal ions from aqueous acid solutions onto TDA impregnated resin," Journal of Radioanalytical and Nuclear Chemistry, vol. 270, no. 3, pp. 559-566, 2006.

[26] M. Merdivan, M.Z. Düz, and C. Hamamci, "Sorption behaviour of uranium(VI) with N,N-dibutyl-N/-benzoylthiourea impregnated in amberlite XAD-16," Talanta, vol. 55, no. 3, pp. 639-645, 2001.

[27] M. S. Hosseini, A. Hosseini-Bandegharaei, H. Raissi, and F. Belador, "Sorption of $\mathrm{Cr}(\mathrm{VI})$ by Amberlite XAD-7 resin impregnated with brilliant green and its determination by quercetin as a selective spectrophotometric reagent," Journal of Hazardous Materials, vol. 169, no. 1-3, pp. 52-57, 2009.

[28] A. Hosseini-Bandegharaei, M. S. Hosseini, Y. Jalalabadi et al., "Removal of $\mathrm{Hg}(\mathrm{II})$ from aqueous solutions using a novel impregnated resin containing 1-(2-thiazolylazo)-2-naphthol (TAN)," Chemical Engineering Journal, vol. 168, no. 3, pp. 11631173, 2011.

[29] M. S. Hosseini, A. Hosseini-Bandegharaei, and M. Hosseini, "Column-mode separation and pre-concentration of some heavy metal ions by solvent-impregnated resins containing quinizarin before the determination by flame atomic absorption spectrometry," International Journal of Environmental Analytical Chemistry, vol. 89, no. 1, pp. 35-48, 2009.

[30] M. S. Hosseini and A. Hosseini-Bandegharaei, "Selective extraction of Th(IV) over $\mathrm{U}(\mathrm{VI})$ and other co-existing ions using eosin B-impregnated Amberlite IRA-410 resin beads," Journal of Radioanalytical and Nuclear Chemistry, vol. 283, no. 1, pp. 2330, 2010.

[31] A. Hosseini-Bandegharaei, M. S. Hosseini, M. Sarw-Ghadi, S. Zowghi, E. Hosseini, and H. Hosseini-Bandegharaei, "Kinetics, equilibrium and thermodynamic study of $\mathrm{Cr}(\mathrm{VI})$ sorption into toluidine blue o-impregnated XAD-7 resin beads and its application for the treatment of wastewaters containing Cr(VI)," Chemical Engineering Journal, vol. 160, no. 1, pp. 190-198, 2010.

[32] S. B. Savvin, "Analytical use of arsenazo III. Determination of thorium, zirconium, uranium and rare earth elements," Talanta, vol. 8, no. 9, pp. 673-685, 1961.

[33] A. Garcic, "A highly sensitive, simple determination of serum iron using chromazurol B," Clinica Chimica Acta, vol. 94, no. 2, pp. 115-119, 1979.

[34] A. Tabacco, E. Moda, P. Tarli, and P. Neri, "An improved, highly sensitive method for the determination of serum iron using chromazurol B," Clinica Chimica Acta, vol. 114, no. 2-3, pp. 287290, 1981.

[35] Y. Fujita, I. Mori, and M. Toyoda, "Spectrophotometric determination of protein with chromazurol B-beryllium(II) complex by manual and flow-injection methods," Analytical Sciences, vol. 8, pp. 313-316, 1992.

[36] K. Ihara, S.-I. Hasegawa, and K. Naito, "Collection of iron(III) from homogeneous aqueous solutions on membrane filters using Chromazurol B with Triton X-100," Analytical Sciences, vol. 19, no. 2, pp. 265-268, 2003.

[37] V. N. Bulut, C. Duran, M. Tufekci, L. Elci, and M. Soylak, "Speciation of $\mathrm{Cr}(\mathrm{III})$ and $\mathrm{Cr}(\mathrm{VI})$ after column solid phase extraction on Amberlite XAD-2010," Journal of Hazardous Materials, vol. 143, no. 1-2, pp. 112-117, 2007.

[38] C. Duran, A. Gundogdu, V. N. Bulut et al., "Solid-phase extraction of $\mathrm{Mn}(\mathrm{II}), \mathrm{Co}(\mathrm{II}), \mathrm{Ni}(\mathrm{II}), \mathrm{Cu}(\mathrm{II}), \mathrm{Cd}(\mathrm{II})$ and $\mathrm{Pb}(\mathrm{II})$ ions from environmental samples by flame atomic absorption spectrometry (FAAS)," Journal of Hazardous Materials, vol. 146, no. 1-2, pp. 347-355, 2007.

[39] A. Gundogdu, C. Duran, H. Basri Senturk, L. Elci, and M. Soylak, "Simultaneous preconcentration of trace metals in environmental samples using amberlite XAD-2010/8hydroxyquinoline system," Acta Chimica Slovenica, vol. 54, no. 2, pp. 308-316, 2007.

[40] D. Muraviev, "Surface impregnated sulfonate ion exchangers: preparation, properties and application," Solvent Extraction and Ion Exchange, vol. 16, no. 1, pp. 381-457, 1998.

[41] D. Muraviev, L. Ghantous, and M. Valiente, "Stabilization of solvent-impregnated resin capacities by different techniques," Reactive and Functional Polymers, vol. 38, no. 2-3, pp. 259-268, 1998.

[42] I. Langmuir, "The constitution and fundamental properties of solids and liquids," Journal of the American Chemical Society, vol. 38, no. 2, pp. 2221-2295, 1916.

[43] M. J. Tempkin and V. Pyzhev, "Kinetics of ammonia synthesis on promoted iron catalysts," Acta Physiochimica URSS, vol. 12, pp. 217-222, 1940.

[44] H. Freundlich, "Uber die adsorption in lunsungen," Journal of Physical Chemistry, vol. 57, pp. 387-470, 1985.

[45] M. N. Bale and A. D. Sawant, "Solvent extraction and spectrophotometric determination of uranium(VI) with pyridine-2-carboxaldehyde 2-hydroxybenzoylhydrazone," Journal of Radioanalytical and Nuclear Chemistry, vol. 247, no. 3, pp. 531-534, 2001.

[46] J. L. Guzmán Mar, L. López Martínez, P. L. López de Alba, N. Ornelas Soto, and V. Cerdà Martín, "Multisyringe flow injection spectrophotometric determination of uranium in water samples," Journal of Radioanalytical and Nuclear Chemistry, vol. 281, pp. 433-439, 2009.

[47] M. J. Benoliel and P. Quevauviller, "General considerations on the preparation of water certified reference materials," Analyst, vol. 123, no. 5, pp. 977-979, 1998. 

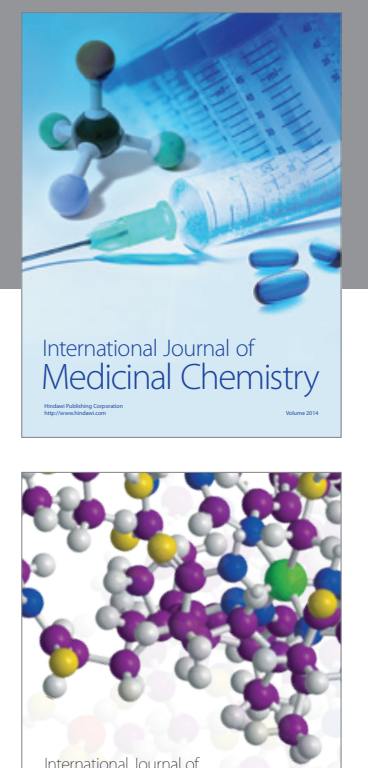

\section{Carbohydrate} Chemistry

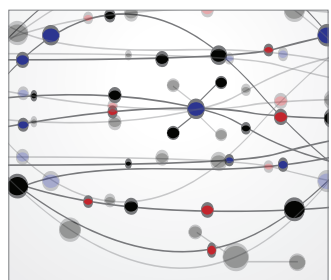

The Scientific World Journal
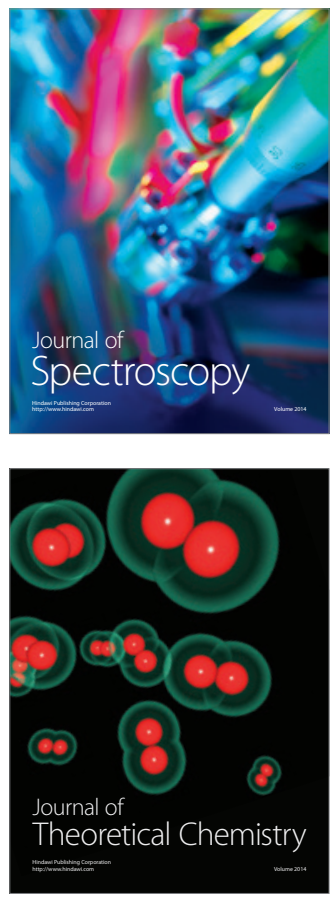
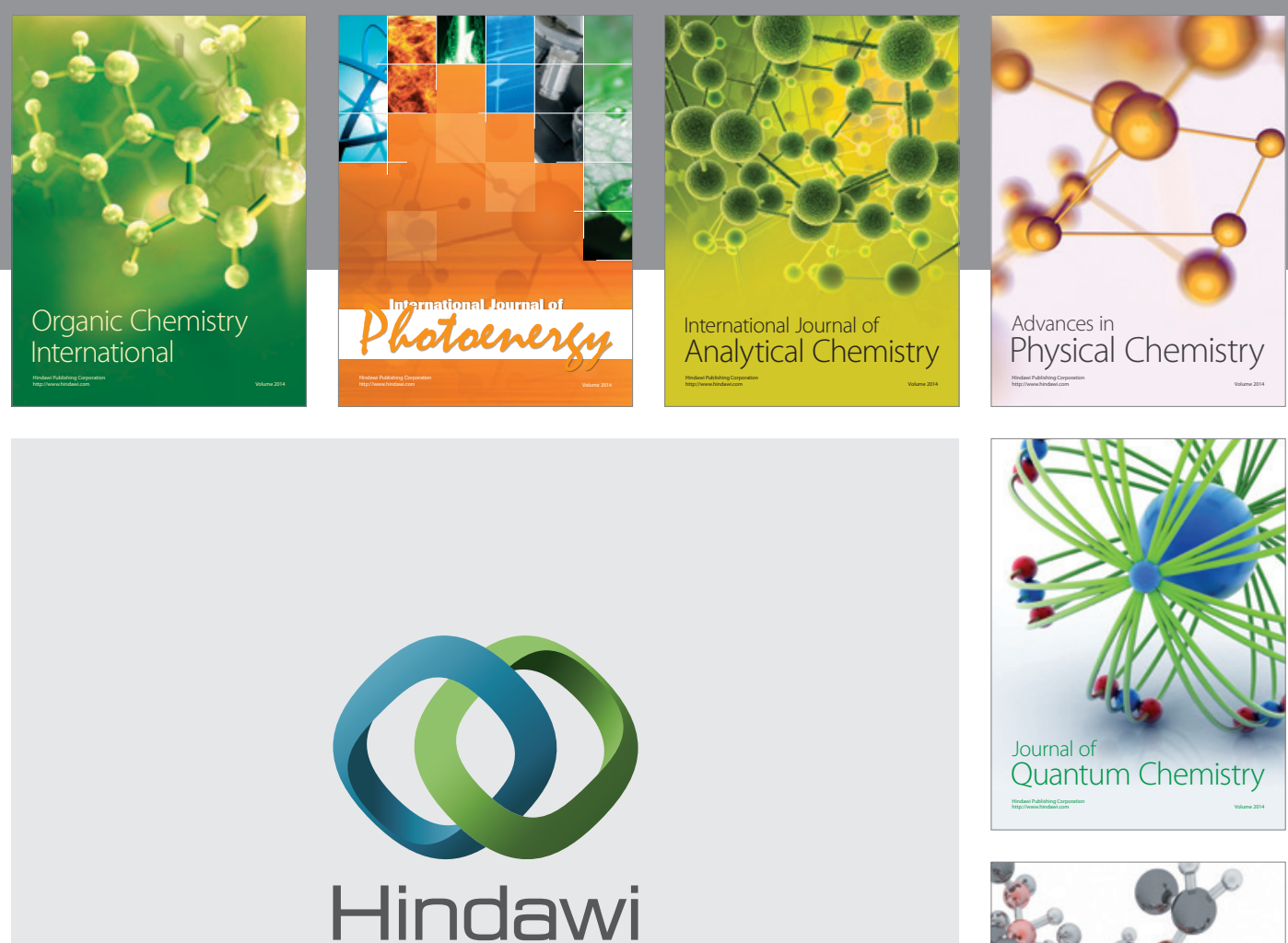

Submit your manuscripts at

http://www.hindawi.com

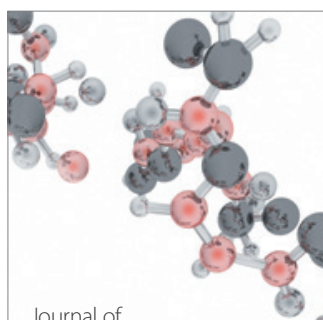

Analytical Methods

in Chemistry

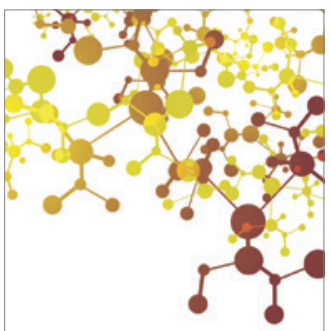

Journal of

Applied Chemistry

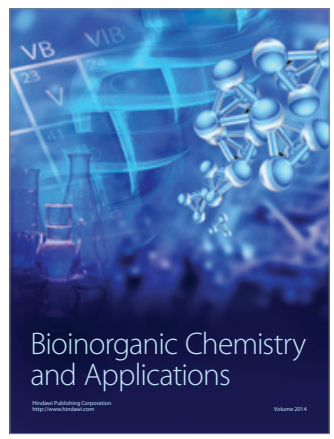

Inorganic Chemistry
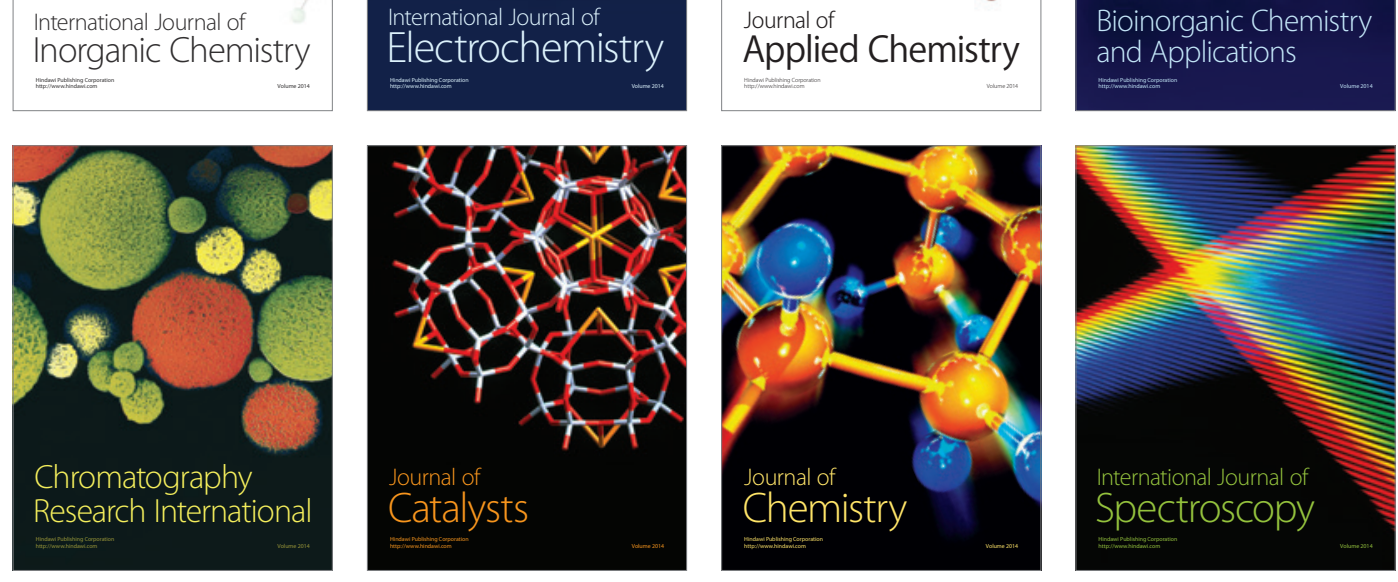